\title{
Approaches to Nordifikation of High-Latitude Construction Engineering
}

\author{
Ivan S. Inzhutova, Viktor I. Zhadanov ${ }^{\mathrm{b}}$, \\ Andreas Falk ${ }^{c}$, Rashit A. Nazirova, \\ Sergey P. Amelchugov ${ }^{\mathrm{a}}$ and Evgeny A. Chaikin*a \\ ${ }^{a}$ Siberian Federal University \\ 79 Svobodny, Krasnoyarsk, 660041, Russia \\ ${ }^{b}$ Orenburg State University \\ 13 Pobedy, Orenburg, 460018, Russia \\ ${ }^{c}$ KTH Royal Institute of Technology \\ SE-100 44, Stockholm, Sweden
}

Received 01.10.2018, received in revised form 10.01.2019, accepted 01.02.2019

The simple mechanical transfer of structural technologies to high-latitude construction engineering is not efficient. But construction engineering nordifikation seems to be effective and expedient, for example working camps. Severe, extreme conditions in the Arctic are similar to extraterrestrial, for example, Martian therefore use of space technologies is required here. From this point of view, it is expedient to build space frame constructions such as: domes, lenses, spheres, Rello's cones united by the covered transitions of ribbed type or the common covering, having good aerodynamics. In this article is emphasized the rationality of designs made of timber itself and wood materials that defines need of creation of the glued elements industry, that is possible only in presence of government support.

Keywords: Arctic development, nordifikation, working camp, designing and engineering principles in high latitudes, aerodynamics, energy efficiency, government support.

Citation: Inzhutov I.S., Zhadanov V.I., Falk A., Nazirov R.A., Amelchugov S.P., Chaikin E.A. Approaches to nordifikation of high-latitude construction engineering, J. Sib. Fed. Univ. Eng. technol., 2019, 12(2), 222-230. DOI: 10.17516/1999-494X-0131.

(C) Siberian Federal University. All rights reserved

This work is licensed under a Creative Commons Attribution-NonCommercial 4.0 International License (CC BY-NC 4.0).

* Corresponding author E-mail address: dubrovskayaolga@mail.ru 


\title{
Подходы к нордификации
}

\section{высокоширотного строительства}

\author{
И.С. Инжутов ${ }^{\text {a }, ~ В . И . ~ Ж а д а н о в ~}{ }^{\tilde{\sigma}}$ А. Фальк \\ P.А. Назиров ${ }^{a}$, С.П. Амельчугов ${ }^{\text {a }}$, Е.А. Чайкин ${ }^{a}$ \\ ${ }^{a}$ Сибирский федеральный университет \\ Россия, 660041, Красноярск, пр. Свободный, 79 \\ ${ }^{6}$ Оренбургский государственный университет \\ Россия, 460018, Оренбург, пр. Победы, 13 \\ ${ }^{6}$ Королевский технологический университет \\ Швеция, Стокгольм
}

Простой механический перенос строительных технологий в высокоширотное строительство неэффективен. Целесообразна нордификачия строительства, например вахтовых поселков. Суровые, экстремальные условия в Арктике подобны внеземным, поэтому здесь требуется применение космических технологий. Целесообразно возведение зданий в виде пространственных сооружений: куполов, линз, сфер, конусов Релло, объединенных крытыми переходами нервюрного типа или общим покрытием, обладающих хорошей аэродинамикой. Подчеркивается рациональность конструкиий из дерева и древесных материалов, что определяет необходимость создания индустрии клееных элементов, а это возможно только при наличии государственной поддержки.

Ключевые слова: освоение Арктики, нордификация, космические технологии в строительстве, деревянные пространственные сооружения, вахтовые поселки, принципы проектирования и строительства в высоких широтах, аэродинамика, энергоэкономичность, государственная поддержка.

\section{Introduction}

Advance of Russia to the east and to the north for centuries was bound to searching of available resource base. From the pragmatical, economic point of view development of resources in high latitudes demands well-timed creation of new technologies [1].

According to many scientists, development of Arctic, for example, is similar to development of the Moon or Mars. If not to consider presence of air and water, then for the rest the Arctic construction a little what differs from construction on Mars [2] in:

- the lengthiest (260-270 days) severe winter and short (90-105 days) cool summer, polar night and polar day;

- continuous spread of permafrost with a power up to $400 \mathrm{~m}$ with a temperature of a frozen soil from $-1{ }^{\circ} \mathrm{C}$ to $-10{ }^{\circ} \mathrm{C}$;

- permafrost, underground ices, cryopeg;

- high intensity of snow kiddle up to $2000 \mathrm{~m}^{3} / \mathrm{p} . \mathrm{m}$., and on the north of Yamal to $4000 \mathrm{~m}$ p.m., blizzards, snowstorms, constant wind with speeds more than $30 \mathrm{~m} / \mathrm{s}$;

- temperature inversions;

- deficiency or lack of local standard structural materials and building industry [3].

According to authors, economic efficiency of development of high-latitude territories directly depends on the structural technologies applied here - special, space technologies, in other words the 
construction nordifikation is necessary. Nordifikation (Northernness) - the term offered by the Canadian geographer Luik Edmond Gamelin for designation of a northern state or quality and recognized by the Arctic Council as the worked [4]. It means the maximal adaptation to extreme conditions for the purpose of creation the comfortable biotic environment, based on the last achievements of science and structural technologies.

Traditional materials such as concrete, reinforced concrete, steel cause unacceptably high resource intensity on all technological line-up of structural production in northern regions.

It is necessary to point wood underestimation as very efficient structural material in highlatitude construction. In addition, it was widely used here and proved in the best way from positions of frost resistance, small susceptibility to corrosion from blizzards, high unit strength and small heat conductivity for a long time. Of course, now it is about the modern hi-tech materials in the form of glued wood, LVL and other similar [5].

Creation of housing in the Polar region is one of the main Russian architectural and town-planning tasks. Naturally, attempts to transfer habitual forms of the organization of life of the inhabited places to these conditions mechanically will not bring success [6].

To suggest an idea of expediency of construction and buildings of a streamline shape helps the pictures of a surface relief of Mars made from the spacecraft of Mars-express [7, 8]. Strikes a huge number of absolutely ideal dome constructions (Fig. 2), and at the same time, quite perhaps during removal of the high layer from dust and sand it is probable to find the isolated settlements, similar to those, represented in Fig. 1.

From the point of view of an aerodynamics, energy efficiency and rationality for northern territories are expedient buildings of domes shape(which prototype the dwelling of Eskimos - igloo, the Kazakh or American yurt), the convexo-convex lenses, spheres or cones formed by rotation of a Rello's triangle (Fig. 3) with the bases of platform type [9, 10].

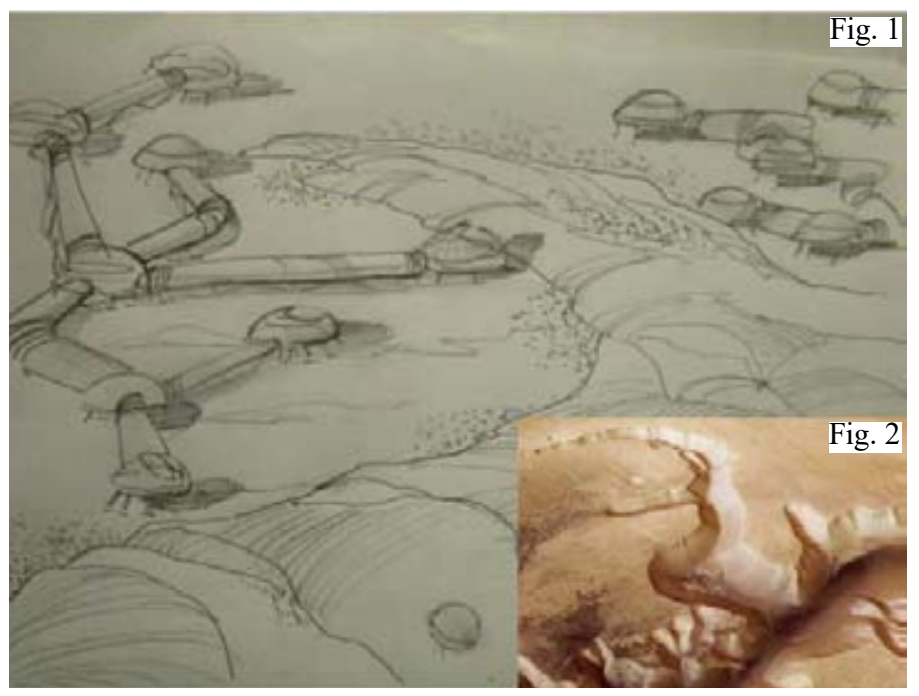

Fig. 1 (at the left), Fig. 2 (on the right). The analysis of a Mars surface picture with the good clearance shows placement of dome-shaped objects around «the Martian hills» - result of a variant of reconstruction on the technogenic scheme [6] 
Constructions should be built on an unstable relief under which - permafrost or even "lens", that is layer of the ice mixed with a soil. In this regard, application of base platforms is efficient also from the point of view of ensuring safe operation in the conditions of degradation of permafrost, and from the point of view of safety early mentioned permafrostIncluding an arrangement of thermal insulation in the bottom, and the elevation of the building over a surface is necessary also for the last circumstance, and for snow blowing-out around the building in order to avoid snow sticking. It is apparent that it is similar to the Martian settlements, buildings can be connected by the galleries (Fig. 4) covered, in particular, transitions of ribbed type ( ribbed vault) for decrease of people's contact with the external environment.

In a number of works is noted rationality of the field camps organization under the «dome» or a translucent covering of awning type arranged on system of ropes (cables) tense between buildings of the different height. Such flexible covering will dump snow itself in case of wind effect (Fig. 5).

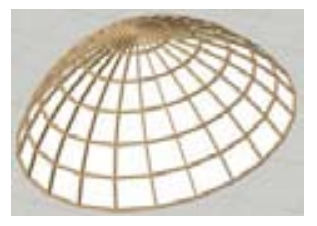

A)

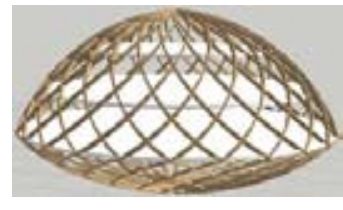

B)

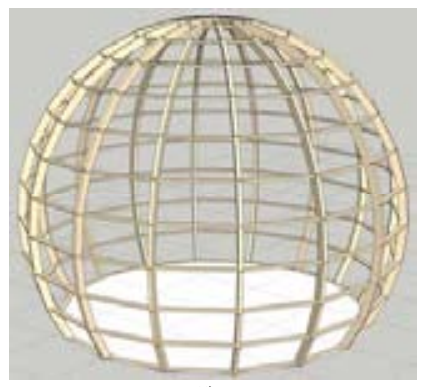

C)

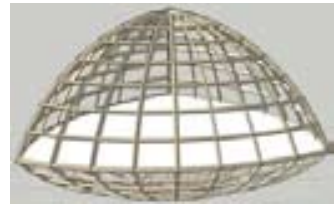

D)

Fig. 3. The key diagrams of possible forms of buildings for the Arctic: dome(a), lens (b), sphere (c), Rello's cone (d)

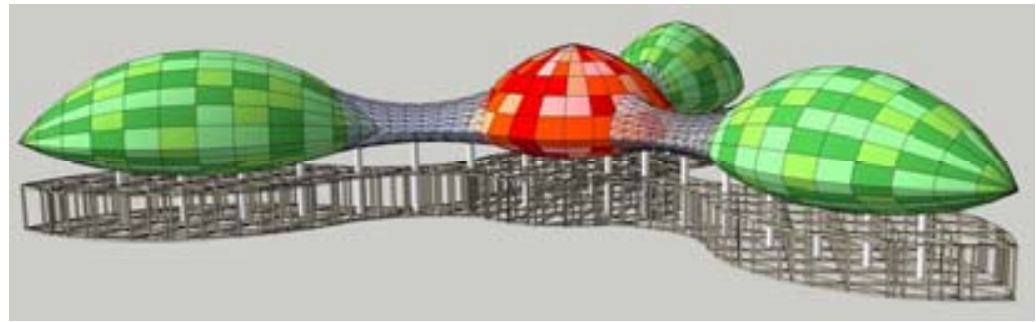

Fig. 4. Connection of buildings by transitions of ribbed type galleries

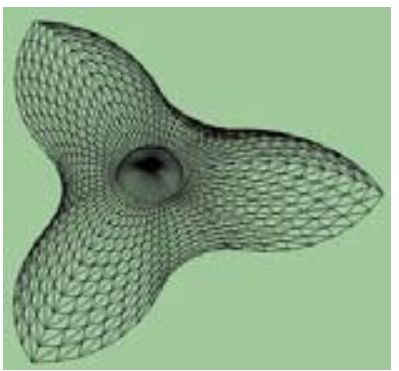

Fig. 5. The key diagram of the settlement under a uniform translucent covering 
A little settlements, which have in the center buildings and constructions of big diameter protected from winds by a toroidal semi-ring (Fig. 6) [11] can be organized in a different way. Amderma - "future capital of the Northern Sea Route".

Prototype for shaping of a complex is the traditional dwelling of Eskimos, so-called «Igloo». Because of the strong winds which average annual speed reaches $5-7 \mathrm{~m} / \mathrm{s}$, and maximum $-35 \mathrm{~m} / \mathrm{s}$ developers of the multipurpose center created an optimum aerodynamic form as streamline system in which a wind will make minimum impact.

The structure of military base (Fig. 7) is efficiently solved [12]. The administrative complex "The Arctic trefoil" is the five-floor trefoil painted in colors of the Russian tricolor, between its rays are situated three ellipsoids - where are located the administrative block, the block of public catering, and also the cultural and leisure center combined with the block of medical care .

It is necessary to add the following to the listed above principles of a nordifikation of construction engineering:

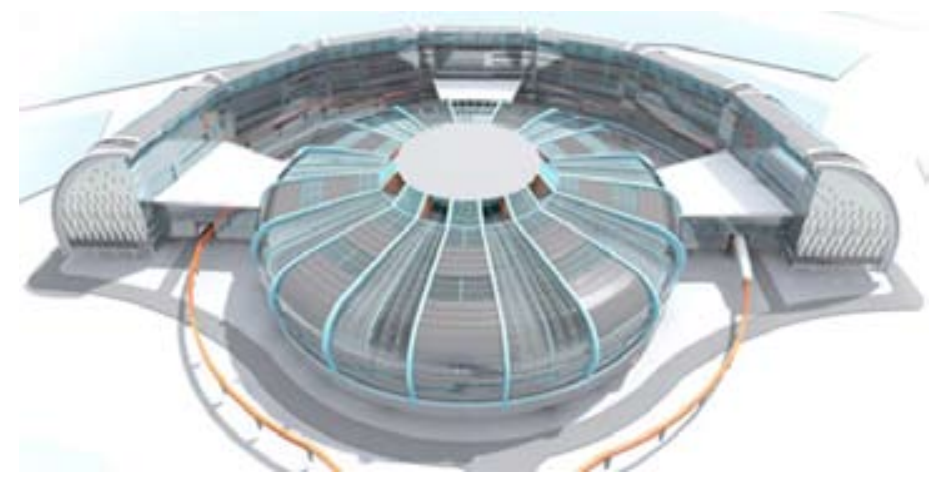

Fig. 6. The multipurpose center for the settlement of Amderma

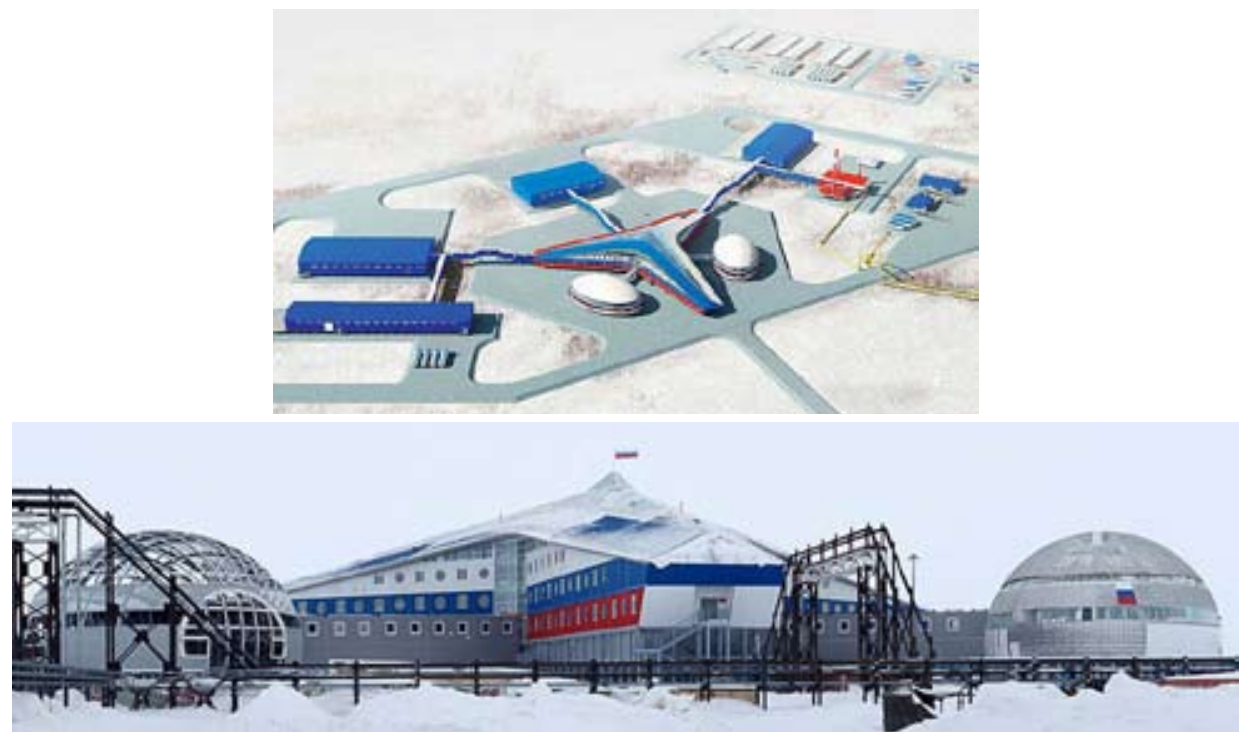

Fig. 7. Military base "The Arctic trefoil" 
- high speed of installation, the maximal level of design's and junction's prefabrication; possibility of installation in all seasons and simplicity of installation works, lack of «wet» processes;

- the commonality of the main load-bearing elements considerably allow to reduce construction cost;

- spatiality and compatibility of element's and structural behavior for the purpose of ensuring mechanical operation safety ;

- ensuring the modern quality of life due to use of innovative technologies [13, 14] which provide economic and environment friendly use of life activity systems .

The special attention in the arctic buildings and constructions has to be given to the latest security systems. The most perspective, in our opinion, is the "predictive path" based on embedding of the corresponding sensors in ventilation and a recuperation systems [15].

For control of condition of buildings and constructions arctic researchers offer to use substances with phase change of the 2nd sort, namely - alloys with thermomechanical shape memory [16]. The elements made of such alloys are at the same time temperature sensing devices and operating mechanism, they are capable to make necessary work at the given temperatures. For example, to signal about achievement of critical depth of frozen soil thawing or to maintain automatically the necessary temperature indoors.

For successful development of the Arctic space it is necessary to provide the industry with replacement of traditional design materials - reinforced concrete and metal on more efficient in a number of parameters wood. It will allow not only to increase technical and economic parameters of the built housing complexes, but also to achieve decrease in «northern price rise» in construction and operation of buildings and constructions in its extreme Arctic form.

Besides the Russian Federation, the USA (Alaska), Canada and all Scandinavian countries, including Denmark treat number of the subarctic states in the northern hemisphere . In southern Chile and Argentina. All of them, except Russia, apply special measures of economic regulation in the relation to the Arctic regions. It is necessary for alignment of competitive conditions for local commodity producers, maintaining the level of their population and further social and economic development.

Each subpolar country forms its own specific policy for the Arctic regions, using the mechanisms of regulation, adequate to their geographical and geo-economics situation, environment and a historical way [17].

In the USA there are special tax modes provided to the enterprises of northern territories remission from income tax, property tax, return sales tax. Ownerships are completely exempted from regional and local taxes. Completely 26 federal ministries are engaged in support of the Arctic regions, and in the Ministry of Trade there is an express division coordinating these efforts.

Canada transfers the process of filling of the budgets to places and supports the Arctic zones by the state grants for alignment of the standard living of the population in a monetary and tax form. In its northern territories the VAT and capital tax is not collected at all, and as for the gas taxes, taxes on the wages fund and on profit -they are significantly less, than in other territory of the country.

Norway, concerning the northern provinces, pursues the policy of the active state inducing for the purpose of preservation in them economic activity and prevention of outflow of the population. These are loans, direct investments in the companies and regional projects, write-off the credits and 
regional extra charges to the salary. The population and the enterprises do not pay VAT for the electric power. Aviation fee on flights within the country does not collected from them at all. For the territory of Spitsbergen is accepted a separate budget.

In Sweden, the government on a constant basis allocates funds for acquisition or updating of fixed assets and the real estate for both beginning enterprises and broadening the production spheres in northern territories. At the same time, preferential terms for tariffs for electricity, motor transport and other.

Finland allocates public funds for the polar territories for development of new production, development of production and internationalization of their activity, creation of work conditions for small and medium-sized enterprises. Besides, there is a redistribution of taxes by return to local budgets up to $85 \%$ of the collected funds; moreover the income tax is significantly lowered.

Denmark subsidizes Greenland and the Faroe Islands by the branch principle: fishery, agriculture and processing industry. The enterprises are given the state guarantees under the credits and tax benefits including ecological.

Larger freedom of economic activity, including international is provided to Subantarctic territories of Chile and Argentina. A part of natural resources, both biological, and resources of a subsoil is transferred to their order. Economy of these countries cannot offer something else more than this.

Considering the experience of other states, it becomes apparent that, without the state support, sustainable development of northern and Arctic territories of Russia is impossible. It can consist of various forms differentiated for our northern regions. It can be a flexible combination of target state investments and a set of tax benefits for territorial subjects of the federation.

The previous social and political structure of our country left considerable inheritance in the form of strong wood-processing branch with extensive logistic network. The city of Lesosibirsk in Krasnoyarsk Krai in which large production capacities on a woodworking are concentrated is a striking example. In a view of of explained above, in our opinion, it is economically efficient and expedient to modernize one of the woodworking plants located here for the purpose of release of glued wooden elements and designs. Existence of the Yenisei River flowing in the meridional direction with an entry in the Northern Sea Route perfectly solves a problem of wooden designs delivery, including wide span, and prefabricated house complexes of different function in high latitudes and any point of the Arctic coast of Russia, and also abroad.

\section{Conclusions}

1. Use of designs from glued and engineering wood in construction of work camps in high latitudes with realization of the described approaches certainly will provide high economic efficiency, guaranteed durability and safety of operation and the most important - the comfortable biotic habitat of people in extreme conditions of the North.

2. Nordifikation of structural branch is impossible without the state support. Programs of federal level have to become the main investor. 


\section{References}

[1] Механик А. Освоение Арктики: необходимо переосмысление. Новости Сибирской науки [A. Mekhanic. Development of Arctic: reconsideration .News of the Siberian science] http:// www.sib-science.info/ru/institutes/ne-otkryta-25072016

[2] Макаров О. Форпост почти на Марсе. Популярная механика, 2016, январь, 159/1. Освоение Арктики: «Севморпуть» возвращается [Makarov O. Outpost almost on Mars. Popular mechanics, 2016, January, 159/1. Development of the Arctic: "Northern Sea Route" comes] backhttp:// www.popmech.ru/weapon/235243-osvoenie-arktiki-sevmorput-vozvrashchaetsya/

[3] Цернант А.А. Инновационные технологии управления температурой грунтовых массивов транспортных сооружений в арктических широтах. Строительные материаль, оборудование, технологии ХХІ века, 2013, 3, 26-29. [Tsernant A.A. Innovative Technologies of Temperature Control of Soil Masses for Transport Facilities in the Arctic. Structural Materials, Equipment, Technology of the 21st century, 2013, 3, 26-29].

[4] Скупов Б. А. Нордификация строительного рынка России [Skupov B.A. Nordifikation of the Russia’s Structural Market] http//www.ids55.ru/ais/articles/ 2010-05-28-02-30-15/2982-2015-1223-12-07-56.html

[5] Five years at Princess Elisabeth Antarctica // International Polar Foundation http://www. polarfoundation.org/news_press/press_pictures/five_years_at_princess_elisabeth_antarctica

[6] Усенюк С.Г. Техносфера Севера: к проблеме проектирования. Научные проблемь транспорта Сибири и Дальнего Востока. 2008, 6, 354-358. [Usenyuk S. G. North technosphere: to a design problem. Scientific problems of Siberia and the Far East transport. 2008. 6. 354-358].

[7] Пунтус В.А., Мясепп К.К. Сценарии реконструкции артефактов (на Марсе и Плутоне) по последним фотоматериалам NASA и ESA . Единый Всероссийский научный вестник, 2016, 11, 43-47. [Puntus V. A., Myasepp K. K. Scenarios of Artefacts Reconstruction (on Mars, Pluto). On the Last Photographic Materials of NASA and ESA . 2016, 11, 43-47].

[8] Фотоматериалы ESA c космического аппарата «Марс-экспресс». Европейское космическое агентство, сайт ESA. [ESA photographic materials from the spacecraft of 'Marsexpress'. European space agency, ESA website].

[9] Абовский Н.П. и др. Новый подход к фундаментостроению для малоэтажных зданий на слабых грунтах. Сочиальные стандарты качества жизни в архитектуре, градостроительстве и строительстве: сб. науч. тр. РААСН. Под ред. А.П. Кудрявцева [и др.]: РААСН, ФГОУ ВПО «Госуниверситет - УНПК», Юго-Зап. гос. ун-т. Москва-Орел-Курск, 2011, 229-233. [Abovsky N.P. New approach to foundation engineering for low buildings on weak soils / N.P. Abovsky, I.S. Inzhutov, S.V. Deordiyev, V.I. Palagushkin, V.A. Si-delev. The Social quality standards of life in architecture, town planning and construction. A. P. Kudryavtsev [etc.]: RAASN, FGOU VPO "State University - UNPK”, Southwest State University. Moscow-Oryol-Kursk, 2011. P. 229-233].

[10] Абовский Н.П. Активное формообразование архитектурно-строительных конструкций зданий и сооружений из унифицированных строительных элементов для строительства в особых грунтовых условиях и сейсмических районах [Abovsky N.P. Development of the System of Geotechnology for Seismic Resistant Construction under Different Complicated Geodynamic Ground Conditions] http://isi.sfu-kras.ru/files/grado/Aktivnoe_form. arh-str._konstr_zdaniy_i_sooruzh.pdf 
[11] Пучков М. Многофункциональный центр для п. г. т. Амдерма [Puchkov M. The multipurpose center for Amderma] http://archobraz.ru/prj/97

[12] «Арктический трилистник»: Уникальный российский военный объект на Крайнем Севере [The Arctic trefoil": A unique Russian military facility in the Extreme North] http://rusvesna. $\mathrm{su} /$ news $/ 1462253000$

[13] Позднякова Ю. Космические технологии для северных широт [Pozdnyakova Y. Space technologies for northern latitudes] http://www.sbras.info/articles/opinion/kosmicheskie-tekhnologiidlya-severnykh-shirot

[14] Дегерменджи А.Г. и др. Принщипы создания экожилья в Арктике (Презентация). Институт биофизики СО РАН, Сибирский федеральный университет. Красноярск, 2015. [Degermendzhi A. G. The principles of creation of ecohousing in the Arctic (Presentation). Institute of biophysics of the Siberian Branch of the Russian Academy of Science, Siberian federal university, Krasnoyarsk, 2015].

[15] Умные дома будут предупреждать о сбое критических систем Популярная механика [Smart houses will warn about failure of critical systems Popular mechanics] http://www.popmech.ru/ technologies/319502-umnye-doma-budut-preduprezhdat-o-sboe-kriticheskikh-sistem/.

[16] Afanasyev Vladimir E., Kondrakov Igor M., Zhadanov Viktor I. Use of Materials with Thermomechanical Shape Memory for Sollution of the Applied Problems in Construction Engineering Complex. Journal Siberian Federal University, 2016, 4(9).

[17] Жуков М. Арктика. Третий подход. Редкие земли. 2015. [Zhukov M. Arctic. Third approach. Infrequent lands. - 2015] http://rareearth.ru/ru/pub/20151103/01739.html 